\title{
Living a piety-led life beyond Muharram: becoming or being a South Asian Shia Muslim in the UK
}

\section{Sufyan Abid Dogra ${ }^{1}$ (1)}

Published online: 8 June 2019

(C) The Author(s) 2019

\begin{abstract}
Reformist British South Asian Twelver Shia Muslims emphasise practising Shia Islam in daily life beyond the month of Muharram by living a piety-led life; they encourage their followers to 'become' a Shia Muslim rather than just 'being' one. The reformist British South Asian Shia ulama, mostly trained in Shia seminaries based in Qom and Najaf, advocate the adoption of an Islamic life-style compatible with the economic, political and social challenges British Muslims face. Many British South Asian Shia Muslims view these piety narratives with contempt. They consider that the narratives on living a piety-led life privilege Islamic lifestyle like praying and reciting the Qur'an daily over Muharram ritual commemorations. These Shia Muslims see the growing popularity of piety-narrative as an apologetic response by Shia reformists to the growing influence of Salafis and the Tablighi Jamaat in Sunni Muslim public spheres. This paper is based on nine months of ethnographic fieldwork among British South Asian Twelver Shia Muslims in London, Birmingham and Bradford. The centrality of commemorating Muharram rituals in Shia Islam becomes contested when reformist Shia Muslims extend the piety-led lifestyle beyond the month of Muharram. This article revisits the anthropological lens of iltizam (commitment) in available studies on piety among Muslim communities. Thus, iltizam for the reformists and religiously upwardly mobile Shia Muslims means subscribing to a globally standardised interpretation of practising Shia Islam that compliments the aspirations of Iran-based Shia religious establishment. For other Shia Muslims, iltizam with Shia Islam is in (i) reenacting the continuity of South Asian ways of commemorating Muharram ritual in Britain and, (ii) opposing the Wahhabi trends in Shia Islam that are endorsed and encouraged by reformist British South Asian Shia Muslims.
\end{abstract}

Keywords Anthropology and Muslim piety - Islamic reformism - Shia Islam in the UK . South Asia · Wahhabi Shia Muslims

Sufyan Abid Dogra

sufyandogra@gmail.com

Extended author information available on the last page of the article 
This article provides ethnographic accounts of emerging narrative by reformist British South Asian Shia Muslims on living a piety-led Islamic life beyond the month of Muharram. ${ }^{1}$ The article analyses this narrative and its manifest emphasis on practising Islam in daily life throughout the year as British South Asian Shia Muslims would do during the month of Muharram. The article evaluates the utility of iltizam (commitment/pledge) as a category of analysis, recently used in anthropological works dealing with piety among Muslim communities (Schielke 2009, 2010; Deeb 2011), and assesses the relevance of ilitizam in studying Shia Islam. I discuss the ethnographic accounts of daily struggles, negotiations and responses about being or becoming a Shia Muslim in Britain. The ethnographic accounts dwell on the popularity, acceptability and contestation of different interpretations on how to live a piety-led life beyond Muharram among two groups of British South Asian Shia Muslims.

For the purpose of analysis in this article, I describe one group of British Shia ulama (religious scholars; sing. alim) and their followers as reformists. Members and followers of the reformist group mostly come from upwardly mobile middle classes, young volunteers, and social and political activists. Reformists encourage Shia Muslims to become 'Islamic modern' (Deeb 2011). Reformists encourage their followers to live a modern life by gaining worldly achievements and success in education, career, business and community affairs. In addition, members and followers are reminded by reformists that they would only become Shia Muslims if they preserve their Shia identity by practising fundamental Islamic tenets like praying five times a day, reciting the Qur'an regularly, fasting during Ramadan, and observing Shia Islam actively throughout the year. Thus, for reformists, combining worldly achievements with preserving and asserting Islamic identity in public sphere, serves as an ideal type of Muslim conduct for daily life. Generally, reformists and their followers have sound understanding of the scholarly traditions of Shia Islam. Most have direct religious learning and exposure from Shia seminaries based in cities like Qom, Mashhad, Najaf, and Karbala in the Middle East (Zahab 2010).

Here, I am using the terms 'Shia Islamic reform' or 'reformism' to have similar meanings as those advanced by Robinson (2008). Islamic reform for Robinson is Muslim ulama and/or authoritative figures asserting a renewed notion of individual behaviour to practise and perform Islam. They do it by making Islam compatible with the challenges and requirements of daily life in a particular space and time. In this article, I interpret Islamic reformism among British South Asian Shia Muslims as an attempt by ulama, leaders and their followers to come up with a standardised, global and authoritative reinterpretation of how to become a Shia Muslim in belief and practice. This reinterpretation meets the adherent's needs in religious and social life, responds to challenges of western modernity and recent global political crises as well as contributes to the theological critique on Sunni Islam by addressing the misconceptions about Shia Islam among Sunni Muslims.

The reformist narrative on living a piety-led life beyond the month of Muharram attempts to introduce a renewed sense of religious identity by reinterpreting a few

\footnotetext{
${ }^{1}$ Muharram, the first month in the Islamic calendar, is the most significant time in the Shia Muslim religious calendar, marked with the commemorations of the martyrdom of third Shia Imam, Husayn ibn 'Ali. The commemorations continue for first ten days rigorously, culminating on the tenth day, 'Ashura'. During Muharram, Shia Muslims observe rituals and participate in commemoration gatherings with religious devotion.
} 
features of being a South Asian Shia Muslim in the UK. First, the reformist narrative evokes a sense of responsibility and commitment (iltizam) in Shia Muslims by promulgating a religious consciousness to Islamise the self, other Shia and the rest of the world; second, this narrative promotes a sense of belonging to a globalised Shia identity by performing standardised ritual commemorations; third, Shia Muslims are sensitized to respond to political affairs with one voice; fourth, the reformist narrative accepts the central authority of religiously-trained ulama and maraji ${ }^{2}$ when it comes to responding collectively to any socio-political situation; fifth, the narrative disparages certain South Asian cultural practices during Muharram commemorations which are revered significantly by some South Asian Shia Muslims. Similar trends of Islamic reformism have been studied among South Asian Sunni Muslims in the nineteenth century, particularly after the end of the Mughal Empire (Metcalf 1982; Robinson 2008; Reetz 2006). Almost a century later, the Iranian revolution in 1979, created the similar effect of Islamic reform among Shia Muslims in minority contexts and among the migrant communities (Roy 2010; Mervin 2010), although the contestations on performance of Muharram rituals already began in the early twentieth century.

The other group of British South Asian Shia Muslims prefers practising Islam through maintaining the supremacy of the ritual commemorations during Muharram over living a piety-led life beyond Muharram. This group believes in the continuity of South Asian traditions of commemorating Muharram (Dogra 2017) is a central mark of Shia identity. The South Asian tradition of Shia Islam in the UK is largely centered around and manifests itself in diverse and often contested public expressions of Muharram rituals (Spellman-Poots 2012; Dogra 2017) to commemorate the martyrs of the Battle of Karbala $(680 \mathrm{CE})$. In this battle, the grandson of Prophet Muhammad and third Imam of Twelver Shia Muslims, Husayn ibn 'Ali (625-680), was martyred along with male members of his family by the ruling Umyyad forces. This was a critical event in Islamic history, known as Ashura (10th day of Muharram), with profound effects on the prevalent schism in Islam until today. Shia Muslims of South Asian origins in the UK reproduce the South Asian (mainly Pakistani and North Indian) ways of commemorating Ashura rituals during the month of Muharram. This is done by organising majalis (religious gatherings; sing. majlis) in Urdu and Punjabi, performing severe zangir zani (sever self-flagellation with blades and knives) by men, and leading Ashura processions in British streets with a decorated horse symbolising zuljina (the horse that Husayn ibn 'Ali rode during the Battle of Karbala). Shia Muslims of South Asian origins recite Urdu, Punjabi, Sindhi and Pashtu marsiya (eulogies) and noha (lamentations) for the martyrs of Karbala with veneration. They exaggerate the spiritual stations and bravery of the martyrs of Karbala. They display an alam (flag associated with martyr 'Abbas ibn 'Ali, step-brother of Husayn ibn 'Ali), distribute langar (food) and organise sabil (serving juices and sweet drinks). Zealous participation in the annual observance of Muharram ritual commemorations is understood as being a pious Shia Muslim among British South Asians.

The public performance and commemoration of these rituals among British South Asian Shia Muslims, however, has not been homogeneous since last couple of decades.

\footnotetext{
${ }^{2}$ The source of emulation for a Shia Muslim to follow, usually a trained religious scholar or an ayatollah with established scholarly and religious credentials.
} 
Each group of Shia Muslims performs diverse and often contested public expressions to commemorate the Battle of Karbala in London (Dogra 2017) and elsewhere in Britain. Nonetheless, these commemorations during Muharram are the most revered occasions for some adherents to give ritual performances as an expression of the most authentic form of practising Shia Islam. For reformists and activists, the same Muharram ritual commemorations become the sites for extending the notions of piety and expanding the scope of practising Shia Islam beyond the month of Muharram.

Shia Muslims in South Asian contexts have been highly visible, in terms of their annual Muharram processions and ritual commemorations, not only during Muharram but throughout the year by holding majalis in the communities they live in; however, until recently, they were invisible in scholarly terms (Robinson 2015). The available studies on Shia Islam in general and South Asian Shia Islam in particular, focus on the marja' al-taqlid, ${ }^{3}$ reformist Shia ulama trained in Iran and Iraq, Shia ritual commemorations, Shia-Sunni relations, and wealthy and politically influential individuals and Shia families (Bayly 1985; Cole 2002; Zaman 1998; Hussein 2005; Pinault 2011; Fuchs 2014; Corboz 2015; Kamran and Shahid 2015). Most of the studies emphasise exploring the transnational networks and connections of Shia maraji', their family relations and inter-marriages and how these maraj' and 'ulama' are shaping the political and religious discourse by advancing Shia responses to local, national and global events (Litvak 2001; Louer 2012; Mervin 2010; Scharbrodt 2011; Khan 2014). However, there is a dearth of scholarship in the existing literature on Shia Islam about the viewpoints of the often neglected and so-called ordinary or common Shia Muslims (Fibiger 2015) on contemporary scholarly, religious and political developments (Shanneik et al. 2017). The subjective and personal reception by Shia Muslims to the scholarly discourses on living a piety-led life, as they are disseminated by Qom and Najaf trained ulama, is a missing link in the existing scholarship on Shia Islam. This problem becomes more pertinent in case of British South Asian Shia Muslims, who constitute a numerical majority (Muslim Council of Britain Report 2015, Ansari 2018) among British Shi'i; yet they do not have enough representation; neither among the Shia religious leaders and authoritative figures in the form of clerical leadership (maraji) nor in the institutional field of the organised Shia Islam (Scharbrodt 2018) as the fieldwork based observations inform. ${ }^{4}$

This article is based on the multiple ethnographic fieldwork which I conducted on various occasions during October 2014 -October 2017 with British South Asian Shia Muslims London, Birmingham and Bradford. I conducted multi-sited ethnographic fieldwork at various locations in the UK for nine months, conducting 68 participant observations of majalis, 44 interviews, and 50 informal discussions with small groups. Out of total amount of data that I collected, a representative selection of ethnographic data has been used in this article. I used pseudonyms for all the research participants in this article.

The emphasis on living a piety-led Islamic life before, during and after the month of Muharram is becoming popular among some sections of Shia Muslims. Reformist British South Asian Shia speakers assert that the objective of Muharram

\footnotetext{
${ }^{3}$ Same as maraji, source of emulation

${ }^{4}$ Most of the maraji', Shia authoritative figures or scholarly Shia Islamic centers in the UK are of Middle Eastern origins, either Iranian or Iraqi backgrounds.
} 
commemorations is learning to live a piety-led life beyond Muharram. The reformist speakers aim at inculcating a renewed understanding of piety, which not only becomes evident through an adherent's public performance of religiosity like praying five times a day, reciting the Qur'an and learning about the teachings of Islam, but also through an emphasis on changing physical appearance of a Muslim in public, his/her social life and an enhanced personal engagement with the propagation of Shia Islamic activities (Zahab 2010; Brunner 2009; Deeb and Harb 2013). The emphasis on living a pietyled life beyond Muharram questions the centrality of ritual commemorations as the piety peak of observing Shia Islam for some British Shia Muslims. The reformists define Muharram commemorations as a medium to enable Shia Muslims to live a pietyled life before and after Muharram.

Emphasis on living piety-led life as a priority over the centrality of Muharram commemorations is not absolutely unique to the British South Asian reformists. The Shii piety narratives in South Asia originated almost a century ago (Naqvi 1942), although these were never accepted by mainstream Shia Muslims in South Asia (Jones 2014; Fuchs 2014; Dogra 2017). A minority of scholars and ulama in South Asia propagated living a piety-led life beyond Muharram and their followers were dubbed as 'Wahhabi Shia', by majority of Shia Muslims in Pakistan. It is pivotal to contextualise the historical continuity of this contestation in South Asia and its contemporary transnational ramifications in Britain. The ethnographic accounts in this article become self-explanatory if the genealogy of Shii piety narrative in South Asia is juxtaposed to the same in Britain.

\section{Emergence of Wahhabi Shia: the South Asian genealogy of piety narratives}

Jones (2014) traces out the historical origins of the piety narratives and finds them embedded in the South Asian Shii writings depicting third Shia Imam, Husayn ibn 'Ali's life and death as a role model for living a piety-led life. Jones (2014) maintains that Syed Ali Naqi Naqvi (1905-1988) wrote hagiography of Husayn ibn’ Ali (1942) which presents Husyan as an ideal, perfect and devout Muslim. Popular Shia beliefs about Husayn ibn 'Ali view him as someone possessing power of intercession with capacity to directly communicate with Allah. Naqvi's depiction of Husayn ibn 'Ali divorces all elements of mythical powers of intercession and divinity that are commonly associated with Husyan and are part of popular Shii beliefs in South Asia. Naqvi (1942) presents him as a moral role-model and does not mention him communicating with Allah directly at the time of his martyrdom. Jones (2014) proposes that depiction of Husayn as a moral exemplar, contrary to popular beliefs, needs to be viewed in the milieu of early twentieth century South Asia. During this time, puritan and reformist movements among Sunni Muslims actively disseminated the narratives of demystification of Sufi saints and emphasised this-worldly aspects of their lives (Metcalf 1982; Robinson 2008). Such a this-worldly identity of the ahl al-bayt ${ }^{5}$ devoid of mythical and intercessory powers was perceived with resentment in the popular

\footnotetext{
${ }^{5}$ According to Shia Muslims views, the five member of the family of Prophet Muhammad (Muhammad, Fatima, 'Ali, Hasan and Husayn).
} 
imagination of South Asian Shia Muslims. The proponents of this-worldly identity of ahl al-bayt are rebuked as 'Wahhabi Shia' in majalis by the majority of South Asian Shia Muslims.

The contemporary emphasis on living a piety-led life in South Asia can be found in the works and religio-political activism of Shia scholar, Muhammad Hussain Dhakku (b. 1933). Dhakku condemned the traditional Shia ulama and zaker ${ }^{6}$ in Pakistan for only speaking about the exaggerated mythical powers of the ahl al-bayt and not educating Shia Muslims to follow them as role models (Fuchs 2014). Dhakku accused traditional Pakistani Shia ulama for their opposition to the establishment of madrassa (Islamic seminaries) as their strategy to keep the Shia populace at a distance from textual knowledge about the true beliefs of Shia Islam. Dhakku emphasised that Shia speakers, zaker (poetry reciters) and ulama needed education along with people (Rieck 2016) about living a piety-led life.

Another Pakistani Shia scholar and activist, Arif Hussain Alhussaini (1946-1988) took a third position, in opposition to both traditional ulama controlling the pulpit and reformist ulama controlling madrassa. His political activism, somewhat, strengthened the reformists but at the same time he accused them of narrowing down the wider political and religious aspects of Shia Islam (Fuchs 2014). When Alhussaini organised a conference on 'Qur'an and Sunna (ways of Prophet)' in collaboration with Sunni Muslims in Lahore, the traditional Shia ulama organised a conference titled 'Qur'an and the ahl al-bayt' on the same day (Fuchs 2014).

The life and works of piety-beyond-Muharram-driven Shia ulama like Naqvi, Dhakku, and Alhussaini in South Asia paved the way for some British South Asian Shia Muslims to adopt the piety narrative without resentment. What was viewed as Wahhabi trends within Shia Islam in South Asia became the mainstream narrative among British South Asian Shia Muslims with a little opposition from within, as the ethnography in this article informs. This could only happen in the context of globalized hyper-diversity in Britain where British South Asian Shii are interacting and engaging with their Iranian and Iraqi counterparts on almost daily basis. Just like the Salafi/Wahhabi puritanical trends became popular among second and third generation of British South Asians Sunni Muslims, the piety narratives gained popularity among young and religiously upwardly mobile British South Asian Shia Muslims. The reformist British Shia Muslims have their transnational religious engagements with Shia Islam between South Asia and Iran/Iraq. The popularity of piety narratives faced opposition and the prioritization of living a piety-led life over ritual commemoration during Muharram became a divisive issue in London (Dogra 2017). The mainstreaming of 'Wahhabi Shia' trends offer another analytical angle for anthropologists writing on piety in Muslim societies to revisit their own conceptions of Muslim piety. The desirability to act as pious and good Muslims can be located and discovered in the British South Asian Shia Muslims' pursuits of either 'being' or 'becoming' a Shia Muslim. Thus, 'being or becoming' offers an ontological turn for a Shia Muslim to connect with Shia Islam as well as it does the same for an anthropologist to revisit Muslim piety by looking beyond the observable expressions of piety.

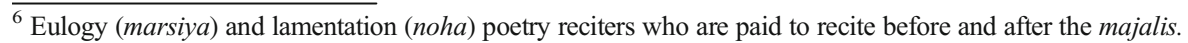




\section{Problematising the anthropological approach on piety in Muslim societies}

Recent anthropological debates have focused on the significance of piety by considering its micro and macro manifestations in the public sphere of Muslim societies. The works of Mahmood (2005), Marsden (2005), Soares and Osella (2009), Schielke (2009), and Deeb (2011) delineate the notions of piety and its relevance in daily life of Muslims around the world. Mahmood (2005) views growing personal and public expressions of piety in Muslim societies as ethical self-fashioning; whereby pious Muslims create coherence in their daily lives through opting for an ethical disposition that doesn't have to belong to any Islamic revival movement necessarily or attempt to challenge western modernity. Other anthropologists extend their analysis about the role of living a piety-led life by locating it in the broader social, economic and political contexts in which Muslim subjectivities are producing, reproducing and responding to the metanarratives of modernity, globalisation, and consumption.

I argue that the emerging discourses by Shia reformists on living a piety-led life beyond Muharram is neither an isolated phenomenon of renewed religiosity nor does it aims for the salvation in the after-life only. Rather, by emphasising on living a piety-led life beyond Muharram, Shia reformists attempt to reproduce uniform Shia Islamic practices in ethnically diverse Shia populations in Britain. The Shia reformists represent themselves as an alternative Muslim umma (imagined community of Muslims) to Sunni Muslims as well as to westren countries and reinforce a standardised global identity of Shia Muslims. They attempt to provide an alternative Islamicated modernity as a normative code offering guidelines on how to live Shia Islam in daily life and become a Shia Muslim in contemporary Britain. The construction of successful-modern-pious identity with its uplifting moral subjectivities may seem appealing for upwardly mobile Shia religious sentiments; however, there is a section of British South Asian Shia Muslims who responds to the perceived standardised Islamisation of their daily lives by reformists with contempt, distaste and suspicion. These Shia Muslims do not subscribe to the reformist narrative on becoming Muslims by living a piety-led life beyond the month of Muharram. At the same time, these Shia Muslims are religiously as well as politically disenfranchised from the project of standardising Shia Islam and its underlying pro-Iranian notion of Shia globalism (Dogra 2017). However, opposing reformist narrative on living a piety-led life beyond Muharram neither makes them any less ambitious about worldly achievement and success in career or business, nor reduces their commitment with Shia Islam. Shia Muslims of South Asian origins in the UK are no exception to the inevitability of contesting the very notion of piety, its meanings (Hegland 1998) and most importantly, how to express it publically in accordance with the tenants of Twelver Shia Islam.

Deeb (2011) advances the debate of piety politics and its relationship to the wider Shia Muslim public sphere. Deeb (2011) argues that anthropological discourses on Muslim piety in the public sphere either deal with the Habermasian notion of the public sphere (Habermas 1991) and how it has shaped Muslim subjectivities, or they limit pious subjectivities to a ethical self-fashioning as Mahmood (2005) would argue. Habermasian view on participation in public sphere restricts it to the educated, bourgeoisie and middle-class only (Reetz 2006). The Habermasian understanding of public sphere emphases on deliberative and communicative aspects of generating a discourse by educated activists. In case of British Shia Muslims, the public sphere effectively becomes a monopoly of reformist ulama and activists. Soares and Osella (2009) argue 
that the emphasis on ethical self-fashioning in anthropological debates about piety have an inherent tendency to ignore or overlook macro-politics within and around Muslim societies. Both argue that neither reducing the relationship between politics and Islam to the epiphenomenon of Islam nor associating piety-mindedness of Muslims to their ethical self-disposition is helpful in understanding how Islam is lived by Muslims (12). Thus, the nuances around Muslim piety cannot be studied with a linear or deterministic approach. This article proposes that understanding Muslim piety by pitting it against secular/liberal westernised individual sensibilities or approaching Muslim piety through western prism of secularity and how it normalises liberal ethos of so-called everyday life would be counter-productive and limit the scope of debate and analysis.

Living piety in daily life is the public practice of authenticating Islam (Deeb 2011). By performing piety, Deeb maintains that Shia Muslims publically manifest the gains of their moral and worldly achievements as an authentication and verification of them being 'Islamic-modern'. Deeb, however, constructs the concept of visible piety making Lebanese Shia Muslims as 'Islamic-modern' by tracing its origin in the commonly shared idea of iltizam (commitment, pledge) amongst them. By becoming multazim (committed), Lebanese Shia Muslims assert their identity in an integrated sense at the community level. A Shia Muslims' iltizam functions in practising Islam as an alternative to the Western lifestyle. Schielke (2009) also presents the similar notion of being morally committed (multazim) by practising Islam among young Egyptians who negotiate the social and economic aspects of life within Islamic reference point vis-àvis western influences. I expand the meanings and utilisation of ilitizam and its relation in becoming a pious-modern Muslim by locating it in the lives of reformists as well as those British South Asian Shia Muslims, who reject reformist narratives of living a piety-led life beyond Muharram. This allows exploring prevalence of the analytical category of iltizam in the lives of those Shia Muslims who don't subscribe to the Islamic reform project and who resent it in some ways. Exploring iltizam in what may otherwise constitute everyday life of Muslims in anthropological works, helps in deconstructing the myth upheld by reformist Muslims and by some anthropologists alike that Muslims outside the Islamic reform project are not Islamic enough and when they live everyday life, they compromise or negotiate being Muslim (Marsden 2005; Schielke 2009; Deeb 2011). This alternative, or the non-reformist way of being pious for British South Asian Shia Muslims is to believe in the centrality of commemorating rituals during Muharram as utmost expression of piety. Iltizam for them is to participate in annual ritual commemoration with zeal and devotion. The purpose of discussing iltizam in the daily lives of these British South Asian Shia Muslims is to shed light on their pious subjectivities and make these subjectivities a part of contemporary academic debates on how Islam is lived. By doing this, I aim to disentangle the anthropological practice of analysing piety by locating its expressions within the realm of any kind of Islamic reform project in Muslim societies.

For Deeb and Schielke, more visibility of being Muslim and practicing Islam in public life equates with being pious-modern and feeling multazim (pledged/committed) among the Muslims. This might be partly true in the case of reformist Muslims. The renewed sense of religiosity among reformist British South Asian Shia Muslims and its public performance responds to local and global affairs such as terrorist attacks in Britain and Europe, sectarian unrest in the Middle East, and the changing or troubled religio-political landscapes in places where Shia Muslims are minority. Hence, the 
emphasis on living a piety-led life beyond Muharram not only endorses an enhanced religiosity and its public visibility by becoming a devout Shia Muslim; it also aligns the personal, social and political subjectivities of an individual with wider socio-political contexts by making them multazim with Shia Islam. This, however, happens at the cost of excluding or demonising those who don't subscribe to the reformist standardisation of Shia Islam in Britain. Developing a direct and linear relationship between visibility of practising Islam and iltizam overlooks or ignores the majority of British and South Asian Shia Muslims who might not be visible Muslims yet remain multazim with Shia Islam, as the ethnography below reveals.

\section{Becoming Shia: reformist narrative on living a piety-led life beyond Muharram}

Reformist Shia speakers and their followers endorse modern, successful, and devout Islamic lives in public sphere. Kazmi, who migrated to the UK from Lucknow, India, is a popular Shia speaker who received his religious qualifications in Qom, Iran. He delivers sermons in the majalis in a husayniyya (Shia Islamic Centre) in London during Muharram and on other occasions. During one of his lectures, he said:

Being a Shia means to be proud of your identity. Why do we hesitate in representing ourselves at public forums where other Muslims are invited to speak? Your conduct in daily life should be best in whatever role you have to perform. You should be best student, best engineer, best teacher, best political leader, best taxi driver and best member of your families etc. Muharram is the time for Shia Muslims to store enough spiritual energy that will keep you pious and make you perform best in your work throughout the year.

Kazmi depicts the life of a devout British Shia Muslim as one where piety is exhibited in work and business while facing the challenges of Western modernity. He encourages the Shia youth to show their commitment (iltizam) with Shia Islam by reading the Qur'an daily, knowing the Islamic discourses on the life of the ahl al-bayt, and confidently representing the Shia Muslim in all walks of life. For Kazmi, it is essential that ulama educate and train Shia Muslims on how to live a piety-led life beyond Muharram and fulfill their responsibility for the wider Shia community. However, some members at a husayniyya in North London have subscribed to the narratives of living a piety-led life because of their own personal interests and experiences. I met Jawad at a husayniyya in North London. Jawad migrated to UK from a rural district in Punjab, Pakistan, in the early 1990s. Jawad told me:

In the early 1980s, religio-political developments among Pakistani Shia were 'hot and new' after the Islamic Revolution in Iran in 1979. I visited Iran and met Ayatollah Khomeini. Afterwards I was a changed person as a Muslim and became an active member of the Imamia Students Organisation (ISO). ${ }^{7}$ I

\footnotetext{
${ }^{7}$ Imamia Student Organisation (ISO) is a Shia student's organisation operating in Pakistan. After the Islamic Revolution in 1979, ISO has been instrumental in mobilising Shia students and youth in Pakistan.
} 
introduced offering daily prayers before or after ISO meetings college mosque and in the husayniyya before the majlis. Unfortunately, the majority of Shia Muslims in Pakistan only know how to say loudly 'Nara-e-Haideri - Ya Ali' [the popular slogan or proclamation of calling for Ali ibn Abi Talib in Shia public gatherings in South Asia], but they have forgotten how to follow the character of 'Ali ibn Abi Talib. In Pakistan, Shia Muslims only know how to raise loud slogans, do sever self-flagellation, cry loud and shed tears in majlis, eat food and leave. Here, in the UK, it is more about doing prayers, reciting the Qur'an and practising Islam in daily life along with attending majalis.

Jawad became a devout Shia Muslim after receiving direct learning from institutions based in Iran. His critique targets fellow Shia Muslims' carelessness in reciting the Qur'an, their lack of knowledge about the scholarly traditions of Shia Islam, their over-indulgence in ritual commemorations during Muharram, and their lesser regard for Islamic rituals such as praying five times a day, giving alms, and fasting during Ramadan. He is multazim (committed) in raising awareness by practising Islam in his daily life and by preaching to fellow Shia Muslims. This is done by sending them messages on living piety-led lives using social media like Facebook and through messages on WhatsApp.

The reformist narrative not only encourages fellow Shia to show iltizam by becoming pious role-models for their brethren, it also seeks to erase what they consider to be contaminating cultural practices. I met Hashmi, a local Shia activist and community leader in Birmingham, who devotes his time to looking after the administrative matters of a local husayniyya. Hashmi shared his frustration about 'extremely deep-rooted cultural practices' among British South Asian Shia Muslims:

A small group of fellow Shia Muslims always meet and greet each other by saying 'Ya Ali Madad (O Ali, help us)'. I told them that the correct Islamic way to meet and greet is by saying al-salamu 'alaykum. Instead of getting embarrassed they laughed at me and told me that they say Ya Ali Madad in public to let others know they are Shia Muslims. It is a pity that they are doing a bid'at (innovation) in the name of Islam. I told them that your love for Imam 'Ali ibn Abi Talib should not misguide you about true Islamic practices.

Hashmi told me that whenever he preaches Shia Muslims, they generally laugh at him and call him a typical 'molvi' (prayer leader). He blames uneducated and illiterate zaker (eulogy and lamentation poetry reciters) for encouraging these cultural practices in the name of love for the ahl al-bayt.

The zaker's role in a majlis is to recite marsiya (eulogy) and noha (lamentation) before and after a learned Shia Islamic scholar delivers a lecture. After the scholar's lecture, the zaker continues reciting lamentation poetry about the martyrs of Karbala while the mourners perform self-flagellation by beating their chests with their hands or with sharp blades and knives. I heard similar condemnations and contempt for the zaker from Abbas, another reformist Shia Muslim, at a London husayniyya. He discouraged the inclusion of the zaker during Muharram commemorations:

The eligibility criteria of a prayer leader or anyone using pulpit for preaching Islam in fiqh ja'fariyya [Shia school of jurisprudence] are that they should be 
knowledgeable, knows the Arabic language, most educated of all, and never breaks promises. Most of the zaker using this pulpit do not have any formal Islamic education, have no Islamic knowledge and most of them don't practice Islam in their life. Some of the zaker even don't know how to recite bismillah (In the name of God [religious formula to initiate actions]). This is simply a disgrace. The organisers of the majalis pay huge amounts of money to these illiterate zaker instead of spending money on providing Islamic education for children in the husayniyya.

Like other reformist 'ulama' of South Asian background in the UK, Abbas condemns the role of zaker during the commemorations of Muharram for a variety of reasons. Traditionally, a zaker while reciting marsiya or noha in majalis in the UK is expected to invoke the cultural memory of South Asian communities about ritual performance; to reintroduce South Asian ways of commemorating Muharram rituals; to engage poetically in storytelling about Karbala using Urdu, Punjabi, Seraiki, Sindhi and Pashtu linguistics expressions over English, Arabic and Farsi expressions; to quote examples from life in villages in South Asia rather than sharing daily life examples of Shia Muslims living in the UK; exaggerate the merits, spiritual stations, mythical powers of the ahl al-bayt; and most importantly, belittle and undermine the Islamic practices like offering prayers five times a day or reading the Qur'an. A zaker disseminates overall religious subjectivities of Shia Islam infused with cultural sentimentalities. The disseminations by a zaker in majlis are counter-productive for reformist ulama's piety driven agenda for the standardisation of Muharram rituals among British South Asian Shia Muslims on the lines of Iranian official Muharram commemoration styles where self-flagellation is forbidden.

The zaker endorses the zeal, emotionality and sentimentality shown by an individual during Muharram commemorations as a sole criterion for being pious Shia Muslim. A zaker's narrative on piety suggests that it is not the number of prayers offered or verses of Qur'an recited that will turn a Shia Muslim into a pious individual. On the contrary, it is the number of tears dropped from eyes while crying for the martyrs of Karbala during a majlis and the number of the drops of blood spilled by self-flagellations with blades and knives on the day of 'Ashura', which will enhance the spiritual station of a Shia Muslim in the eyes of the ahl al-bayt. A zaker's understanding of iltizam for Shia Islam and piety is qualitatively different from that of reformists. For a zaker, the commitment with Shia Islam can be determined through the performance during Muharram rituals with emotionality and zeal. Unlike the reformists, who view piety among Shia Muslims in adopting Islamic lifestyle beyond the month of Muharram by becoming a Shia Muslim, a zaker introduces an alternative sense of piety by being a Shia Muslim.

\section{Being Shia: narrative on living a piety-led life through Muharram ritual commemorations}

Despite the popularity of reformist narratives on living a piety-led life before and after the month of Muharram, their acceptability, approval, reception and response is not uniform and majority of British South Asian Shia Muslims reject them. These Shia 
Muslims interpret piety by embedding its merits into the continuity of their cultural identity, historical experience, lived realities, local circumstances and an emphasised distinction from Sunni Islam. For these Shia Muslims, the devotion and zeal with which a Shia publically performs the rituals of Muharram, like crying loud and shedding tears during majalis and performing self-flagellation, will determine the level of piety and will inform others how multazim Shia that person is. Furthermore, this alternative understanding of piety and public performances associated with it are not advanced in response to the reformist narratives on piety. The emotional and zealous performances during Muharram rituals are viewed as being a Shia Muslim.

To clarify, the two groups of British South Asian Shia Muslims with different understandings on how to live a piety-led life are not necessarily in opposition to one another in all aspects of religious life. On certain aspects of commemorating rituals of Muharram like participating in majalis and leading Ashura processions on British streets, both groups show solidarity. While moral ambiguity or clarity on how to act like a true Shia Muslim in accordance with Islamic teaching determines the position of an individual and opposition to other's doctrinal beliefs, the social context plays a pivotal role in informing the choice of an individual (Simpson 2008). At the same time, there are certain issues around ritual performances where opposite narratives over piety contest each other. These contesting ritual performances generate heated debates between members of both groups, particularly around the issue of zanjir zani (selfflagellation with blades and knives). This has led to a court case and litigation over the control of the building and management of a husayniyya in London (Dogra 2017).

During an interview, my key informant, Akbar from South London, expressed his dissatisfaction about the reformist Shia Muslims. Akbar has been a local Shia leader in a South London husayniyya and was replaced by reformist ulama who took over its administrative control. These reformist ulama and their followers were successful in obtaining a barring order for Akbar and his associates from the courts, accusing them of nuisance and encouraging violent extremist practices like self-flagellation in the name of Shia Islam (Dogra 2017). Akbar said:

You see these so-called ulama are working on the agenda of Iranian religious establishment with aim to have a monopoly over Shia Islam all over the world. These ulama are always encouraging Shia Muslims to recite dua-e-kumail ${ }^{8}$ in the husayniyya and in other public gatherings while they undermine reciting hadithe-kisa. ${ }^{9}$ I grew up in a household where my parents always recited hadith-e-kisa every Thursday evening. Wherever you will see these Iran-backed ulama and their Pakistani friends, you will see them reciting dua-e-kumail in the same way as Sunni Muslim would recite taravih $^{10}$ during Ramadan. They are reluctant to

\footnotetext{
${ }^{8}$ Dua-e-kumail (the supplication narrated by Kumail ibn Zayad, a friend and loyal companion of 'Ali ibn Abi Talib) is a long supplication for gaining spiritual merits. This supplication emphasise the supremacy of God and an individual's devotion to God.

${ }^{9}$ Hadith-e-kisa (narration of the people of cloak) is an account where Prophet Muhammad took his daughter Fatima, grandsons Hasan and Husayn, and son-in-law 'Ali ibn Abi Talib, under a cloak and narrated that 'God desires to purify all of you, the people of my house'.

${ }^{10}$ The extra supplications done by reciting Qur'an during the prayer after the mandatory evening prayer in the month of Ramadan by Sunni Muslims.
} 
recite hadith-e-kisa because it elevates the ahl al-bayt (Prophet's family members).

For Akbar, Shia identity is distinct and is shaped by the historical experiences of persecution at the hands of Sunni Muslims. For him, the Iranian religious establishment and reformists only seek political influence by proposing a rapprochement with Sunni Islam. Akbar believes that by doing so, they undermine the unique identity of Shia Islam, as it developed in South Asia. He views that ulama trained in Iranian Shii seminaries preach standardised ways of conducting majlis where zanjir zani [selfflagellation] is condemned and praying five times a day and reciting Quran is encouraged. According to Akbar, this is Iranian religious establishment's political agenda to introduce a globally standardised pattern of commemorating Muharram rituals. He said that after Iranian supreme leader Khamenei's fatwa (verdict) on impermissibility of self-flagellation in Shia Islam, British South Asian Shia Muslims started changing the pattern of conducting majlis and rituals of commemorating Muharram rituals. For Akbar and his friends in London, iltizam [commitment] for a Shia Muslim is to continue performing the customary ways of doing matam [mourning for the martyrs of Karbala] which for them is the one and only mark of identity for being a Shia Muslim.

I interviewed Zafar in Bradford, a community leader and member of a local husaniyya management committee who attends various religious, political and social gatherings of Shia Muslims across the UK. He echoed similar sentiments about the reformist' disseminations on living a piety-led life before and after Muharram.

Matam [mourning] and zangir zani [self-flagellation with blades] are central to Shia Islam. Every Muharram, it is the mourning for the martyrs of Karbala which defines us who we are. It is disturbing that some Shia are emphasising more and more reciting the Qur'an and saying prayers five times a day while undermining matam. I would remind them that reciting Qur'an was a trick of the enemies of Shia Muslims which they used during the Battle of Siffin. ${ }^{11}$ The Shia Muslims once again have become victims of the same Sunni conspiracy. These ulama expect Shia Muslims to practice Islam like the members of Sunni tablighi jamat. $^{12}$

The zaker (poetry reciter in majlis) driven alternative understanding of piety finds its best defense when its proponents take inspiration from the life and work of Abu Talib ibn Abd Al-Mutalib (539-619), the uncle and guardian of Prophet Muhammad and the father of first Shii Imam 'Ali ibn Abi Talib. Sections of British South Asian Shia Muslims applaud the life and work of Abu Talib as that of an alternative model of living a pious life beyond the month of Muharram. Both Sunni and Shia Muslims agree

\footnotetext{
${ }^{11}$ The Battle of Siffin (657 AD) was fought between first Shia Imam and Fourth Muslim Caliph, 'Ali Ibn Abi Talib and Umayyad forces led by Mu'awiya. The battle remained inconclusive. Ali's army was about to win the battle, when soldiers from Umayyad army displayed copies of the Qur'an on their spears and wanted arbitration and negotiation. Upon seeing Qur'an, a section of Ali's army stopped fighting.

${ }^{12}$ Non-political but orthodox Sunni reformist and piety movement which call for its members to live their life according to the teachings of Islam. Tablighi Jamat emphasis on saying prayers five times a day, reciting the Qur'an, learning about Islamic teachings and encourage Muslims to adopt an Islamic dress and appearance.
} 
on the role of Abu Talib as that of a protector, guardian and defender of Prophet Muhammad while the pagan Meccan elites wanted to assassinate or harm him. During one majalis in Bradford, a British Pakistani Shia speaker, Kalib Abbas asserted:

Those who believe that Abu Talib did not recite shahada ${ }^{13}$ before he died, always baffle me. What they do believe is that the Prophet was named as Muhammad by his uncle Abu Talib. How can someone say shahada by using the name of Prophet given to him by Abu Talib and at the same time believe that Abu Talib died as a non-Muslim. When people tried to stop the Prophet from worshipping Allah, Abu Talib said: 'Don't worry my nephew, worshipping to Allah is your duty and defending you and Islam is mine and that of my children.'

Zafar told me that the over-emphasis on praying was the characteristic of Satan which could not save him from becoming the enemy of Allah. The belief, affinity and defense of Abu Talib for the Prophet Muhammad serves as a prototype and an ideal type of alternative way of being pious which surpasses praying, supplications and reciting the Qur'an. Some British Shia Muslims assert that Abu Talib did not engage in formal acts of worship throughout the year, even though he was a Muslim, but is rewarded for defending Prophet Muhammad and Islam. The same is also emphasised by zaker who reject the standardisation of Muharram commemorations and belittle reformist's narratives on extending the notion of piety beyond Muharram. The popular belief among British South Asian Shia Muslims is that defending Islam by advocating the superiority of ahl al-bayt determines anyone's commitment to Shia Islam. Iltizam for these Shia Muslims is in continuity of the tradition of matam and preservation of historical Shia identity which evolved and developed in South Asia in opposition to Sunni Islam. By annual reenactment of Muharram rituals in line with their Shia brethren in South Asia, these British South Asian Shia Muslims show they are multazim to Shia Islam without subscribing to the reformist project.

The ethnography presents that iltizam-driven piety is possible to attain without performing it daily and publically for those Shia Muslims who stand at the margins of Islamic reform project. For Lambek (2000), performing moral behaviour by an individual is a rational act of making a choice while negotiating and balancing various other commitments in life. Hirschkind (2006) argues that people chose to listen to audio cassette sermons by Muslim preachers in Cairo and the popularity of these cassettes among Muslim audience was their attempt to induce Islamic normative subjectivity pitted against secular viewpoints and ideals they confronted with in their daily lives. Here, arguably, the recitation of zaker for South Asian Shia Muslims in the UK inculcate living a piety-led life through their experiential, emotional and performative understanding of being Muslim draws a parallel to the narratives on living a piety-led life by pro-Iranian reformist 'ulama'. This informs us that the practising Islam and consuming piety in daily life can embed itself in experiential, discursive and subjective micro realities with aim at balancing out meta-narratives of pro-Iranian standardising Shia rituals without compromising being multizam (committed).

\footnotetext{
${ }^{13}$ The words 'I bear witness that there is not god but God and Muhammad is the Messenger of God" which every Muslim utters to declare his or her beliefs in Islam. The ritual utterance of these words is required for anyone who converts to Islam.
} 


\section{Understanding Muslim piety through iltizam}

In available anthropological studies on Muslims societies or on Muslims living in western contexts, the instrumental analysis of iltizam (commitment) results in piety-reductionism whereby a Muslims' lived experience with Islam is analyzed through their observable acts of worship or by their association with any Islamic reform or revival movement (Deeb 2011, Schielke 2009). Iltizam, in these analyses, appears like a centripetal force that keeps a Muslim rotating on the axis of Islam while a standardised interpretation of practising Islam by reformists operates as the centre of rotation. This article explores the sense of iltizam in the lives of Muslims who don't subscribe to any Islamic reform project. I argue that non-affiliation with any Islamic reform project among sections of British South Asian Shia Muslims operates as centrifugal force that keeps them on/within the orbit of Islam. From the reformists' viewpoint or through anthropological observation obsessed with what is visible and can be calculated and measured, these Shia Muslims might appear to be on the margins or peripheries of Islam. However, the centrifugal nature of their affiliation with Shia Islam helps non-reformist Shia Muslims to position themselves at a distance from standardisation process of commemoration of Muharram rituals.

Anthropological studies on Muslim piety limit the prevalence of iltizam in the lives of 'good Muslims' through observing them from the prism of Islamic revival emphasizing on prayers five times a day, fasting, supplications and reciting the Qur'an throughout the year, and maintenance of so-called Islamic attire and appearance like hijab and beards. The ethnography in this article informs that among British South Asian Shia Muslims, the spirit, devotion and zeal of being a good Muslim produces an alternative sense of their iltizam with Shia Islam. These Shia Muslims will trace ways of being pious in connection with the historical experience of South Asian Shia Islam, emotional performances during Muharram commemorations like crying loud during majalis and Ashura procession, shedding tears, performing severe self-flagellation and opposing Sunni Islam. By doing this, British South Asian Shii not only response to reformist Shii standardisation of rituals, but also maintain and preserve their distinctive cultural ritual performances and opposition to Sunnis Islam. This way of being multazim provides a plethora of meanings to ensure the continuity of historical experiences embedded in peculiarity of just being Shia Muslim and stay pious and devout by commemorating Muharram rituals. For the rest of the year, these Shia Muslims will reject and oppose the pro-Iranian reformist narrative of living a piety-led life by negating what they view as Sunni ways of being Muslim. In both understandings of iltizam among Shia Muslims, commitment with Islamic identity remains central. Deeb (2006) and Schielke (2009) locate the scope of being pious-modern Muslim with the Muslim reformists, volunteers, activists and those who pledge their lives publically to practice Islam, individually or by affiliating with a group. This limits the prevalence of iltizamiltizam with Islam among the religiously upwardly mobile Muslims only.

For Shia Muslims in the UK, being pious becomes a subjective experience and the manifestation of pious modernity through ritual commemorations does not bind them to subscribe to one particular interpretation of becoming Muslim. By just being a Shia Muslim during Muharram, piety-led life is lived through preserving South Asian ways of being Shia Muslim, without compromising historical continuity and culturally-specific expressions of Muharram ritual commemorations. For reformist Shia Muslims, being pious-modern becomes another religious landscape where they manifest and align with globally standardising interpretations of becoming a good Muslim beyond Muharram. 
The recent anthropological writings on piety among various Muslim societies usually confine the scope of analysis to observable expressions of public or individual piety which are generally advanced by reformist or revivalist Muslims or associated with growing influence of Salafi and other Islamic groups (Marsden 2005; Osella and Osella 2008; Simpson 2008; Schielke 2009; Deeb 2011). The ethnography of this article suggests that without becoming a part of Islamic reform project, South Asian Shia Muslims in the UK live a piety-led life by just being Shia Muslim without going through the trouble of becoming one. Staying multazim for preservation of their religious identity is done by rejecting pro-Iranian standardising Shia reformism and by maintaining their distinction to Sunni ways of Isalmisation of daily life. Locating modern Muslim piety in observable, tangible or organised religious expressions of Muslims would limit the scope of analysis of piety among Muslims communities to; a) religiously upwardly mobile Muslims, b) generate Eurocentric positivistic epistemologies to study pious daily life of Muslims by focusing on what can be calculated or observed, c) reduce it to a Habermasian framework to examine the Muslim public sphere and, d) overlook alternative expressions of Muslim piety, and e) will make anthropologists observe and analyse Shii piety expressions on Sunni criteria and expressions of piety. Nonetheless, terming British South Asian Shii who reject standardising reformist Shia narrative as secular, traditionalist or 'backward' Muslims will be insufficient and unwarranted to delineate their religiosity and religious identity. I maintain that social, political and economic factors are at play for the politically disenfranchised Shia Muslims who are opponents to the pro-Iranian reformist narratives on living piety-led life beyond the month of Muharram in the same way as these factors are instrumental in advancing the argument of proponents of Islamic reform.

Open Access This article is distributed under the terms of the Creative Commons Attribution 4.0 International License (http://creativecommons.org/licenses/by/4.0/), which permits unrestricted use, distribution, and reproduction in any medium, provided you give appropriate credit to the original author(s) and the source, provide a link to the Creative Commons license, and indicate if changes were made.

\section{References}

Ansari, H. (2018). The infidel within': Muslims in Britain since 1800. London: Hurst \& Company.

Bayly, C. A. (1985). The pre-history of 'communalism'? Religious conflict in India, 1700-1860. Modern Asian Studies, 19(2), 177-203.

Brunner, R. (2009). Shiism in the modern context: From religious quietism to political activism. Religion Compass, 3(1), 136-153.

Cole, J. (2002). Sacred space and holy war: The politics, culture and history of Shi'ite Islam. London: I. B. Taurus.

Corboz, E. (2015). Guardians of Shi'ism: Sacred authority and transnational family networks. Edinburgh: Edinburgh University Press.

Deeb, L. (2011). An enchanted modern: Gender and piety in Shi'i Lebanon public. Princeton University Press.

Deeb, L., \& Harb, M. (2013). Choosing both faith and fun: Youth negotiations of moral norms in South Beirut. Ethnos., 78(1), 1-22.

Dogra, S. A. (2017). Karbala in London: Battle of expressions of Ashura ritual commemorations among Twelver Shia Muslims of south Asian background. Journal of Muslims in Europe, 6(2), 158-178.

Fibiger, T. (2015). Marja'iyyah from below: Anthropological approaches to the study of religious authority. Journal of Shi'a Islamic Studies, 8(4), 473-489.

Fuchs, S. W. (2014). Third wave Shi'ism: Sayyid Arif Husain al-Husaini and the Islamic revolution in Pakistan. Journal of the Royal Asiatic Society (third series), 24(3), 493-510.

Habermas, J. (1991). The structural transformation of the public sphere. An inquiry. Cambridfge. MIT Press.

Hegland, M. E. (1998). Flagellation and fundamentalism:(trans) forming meaning, identity, and gender through Pakistani women's rituals of mourning. American Ethnologist, 25(2), 240-266. 
Hirschkind, C. (2006). The ethical soundscape: Cassette sermons and Islamic counterpublics. Columbia University Press.

Hussein, A. J. (2005). The mourning of history and history of mourning: The evolution of the ritual commemoration of the Battle of Karbala. Comparative Studies of South Asia, Africa and the Middle East, 25(1), 78-88.

Jones, J. (2014). Shi 'ism, humanity and revolution in twentieth-century India: Selfhood and politics in the Husainology of 'Ali Naqi Naqvi. Journal of the Royal Asiatic Society (Third Series), 24(3), 415-434.

Kamran, T., \& Shahid, A. K. (2015). Shari'a, Shi'a and Chishtiya revivalism: Contextualising the growth of sectarianism in the tradition of Sialvi saints of Punjab. In J. Jones \& A. Qasmi (Eds.), The Shi'a in modern South Asia: Religion, history and politics (pp. 159-178). Cambridge: Cambridge University Press.

Khan, M. A. A. (2014). Local nodes of a transnational network: A case study of a Shi'i family in Awadh, 1900 - 1950. Journal of the Royal Asiatic Society, 24(3), 397-413.

Lambek, M. (2000). Nuriaty, the saint and the sultan: Virtuous subject and subjective virtuoso of the postmodern Colony. Anthropology Today, 16(2), 8-12.

Litvak, M. (2001). Money, religion and politics: Oudh bequest in Najaf and Karbala 1850-1903. International Journal of Middle East Studies, 33(1), 1-21.

Louer, L. (2012). Shiism and politics in Middle East. New York: Columbia University press (2008). In Transnational Shia politics: Religious and political networks in the Gulf. London: Hurst Publishers Limited.

Mahmood, S. (2005). Politics of piety. The Islamic revival and the feminist subject. Princeton University Press.

Marsden, M. (2005). Living Islam: Muslim religious experience in Pakistan's north-west frontier. Cambridge University Press.

Mervin, S. (2010). Introduction. In S. Mervin (Ed.), The Shia world and Iran. London: SAQI.

Metcalf, B. D. (1982). Islamic revival in British India: Deoband, 1860-1900.

Muslim Council of Britain. (2015). British Muslims in numbers: A demographic, socio-economic and health profile of Muslims in Britain. London: MCB.

Naqvi, S. A. N. (1942). Shahid-i-Insaniyat. India: Lucknow.

Osella, F., \& Osella, C. (2008). Islamism and social reform in Kerala, South India. Modren Asian Studies., $42(2 / 3), 317-346$.

Pinault, D. (2011). Horse of Karbala: Muslim devotional life in India. New York: Palgrave.

Reetz, D. (2006). Islam in the public sphere: Religious groups in India (pp. 1900-1947). Oxford University Press.

Rieck, A. (2016). The Shias of Pakistan: An assertive and beleaguered minority. Oxford University Press.

Robinson, F. (2008). Islamic reform and modernities in South Asia. Modern Asian Studies, 42(2/3), $259-281$.

Robinson, F. (2015). Introduction: Shi'a in modern South Asia. In J. Jones \& A. Qasmi (Eds.), The Shi'a in modern South Asia: Religion, history and politics (pp. 1-11). Cambridge: Cambridge University Press.

Roy, O. (2010). The impact of Iranian revolution on the Middle East. In S. Mervin (Ed.), The Shia world and Iran. London: SAQI.

Scharbrodt, O. (2011). Shaping the public image of Islam: The Shiis of Ireland as "moderate" Muslims. Journal of Muslim Minority Affairs., 31(4), 518-532.

Scharbrodt, O. (2018). A minority within a minority?: The complexity and multilocality of transnational Twelver Shia networks in Britain. Contemporary Islam, 1-19.

Schielke, S. (2009). Ambivalent commitments: Troubles of morality, religiosity and aspiration among young Egyptians. Journal of Religion in Africa., 39, 158-185.

Schielke, S. (2010). Second thoughts about the anthropology of Islam, or how to make sense of grand schemes in everyday life.

Shanneik, Y., Heinhold, C., \& Ali, Z. (2017). Mapping Shia Muslim communities in Europe: Local and transnational dimension. Journal of Muslims in Europe., 6(2), 145-157.

Simpson, E. (2008). The changing perspectives of three Muslim men on the question of saint worship over a 10-year period in Gujarat, Western India. Modern Asian Studies, 42(2/3), 377-403.

Soares, B., \& Osella, F. (2009). Islam, politics, anthropology. Journal of the Royal Anthropological Institute, 15(s1), S1, S23.

Spellman-Poots, K. (2012). Manifestations of Ashura among young British Shi'is. Ethnographies of Islam: Ritual performances and everyday practices (pp. 40-49).

Zahab, M. A. (2010). Between Pakistan and Qom: Shi'i women's madrasas and new transnational networks. In F. A. Noor \& Y. Sikand (Eds.), The madrasa in Asia: Political activism and transnational linkages (pp. 123-140). Amsterdam.

Zaman, M. Q. (1998). Sectarianism in Pakistan: The radicalisation of Shia and Sunni identities. Modern Asian Studies, 32(3), 689-716. 
Publisher's note Springer Nature remains neutral with regard to jurisdictional claims in published maps and institutional affiliations.

\section{Affiliations}

\section{Sufyan Abid Dogra ${ }^{1}$}

1 School of History and Cultures, Arts Building, University of Birmingham, Edgbaston, Birmingham B15 2TT, UK 